\title{
AN ERROR ANALYSIS OF THE TRANSFORMATION FROM DIRECT TO INDIRECT SPEECH
}

\author{
Zahratul Idami \\ IAIN Langsa \\ zahratul21idami@gmail.com
}

\begin{abstract}
The objective of the study is to reveal the types of errors made by students in transforming direct to indirect speech in the form of statements. Furthermore, it attempts to find out the kind of errors that the students do most. To achieve the objectives of the study, the writer conducted a field research in which a test of grammar was administered. Then she did the library research in order to find some books and references that were related to error analysis and grammar. The subjects of the study were the second grade students of SMA Negeri 2 Peusangan. There were 295 students from which 34 students were taken as the sample. With the intention of drawing representative sample, simple random sampling was applied. The data were in the form of students' scores on the tests. The data shows that the students made errors on the selection of appropriate tenses, pronouns, and adverb of time. The most errors they made were in changing pronoun. In line with the result of the research, the writer suggested that to improve the students' ability in transforming direct to indirect speech, students have to learn more about pronoun, tenses, and adverb of time in turning direct to indirect speech. Additionally, it is essential to the teacher to know that choosing the appropriate pronoun is still hard for the students, so that they have to find a new way to improve it.
\end{abstract}

\section{Keywords}

Error analysis, direct speech, indirect speech

\section{INTRODUCTION}

Richards (1985) states that grammar is a description of the structure of a language and the way in which linguistic units such as words and phrases are combined to produce sentences in the language. Furthermore, Pence \& Emery (1969) as cited in Suhandi (2008) say that grammar treats the constructions, forms, and usage of words. It can be concluded from the 
statements above, it is no doubt that by mastering grammar, the students will be able to speak, to read, and to write English correctly and understandable.

Indirect speech as a topic in grammar is used to express what others have said. Marjannah (n.d.) in a Students Worksheet for SMA states, "Indirect or reported speech refers to the use of noun clause that reports what someone has said. No quotation marks are used in it." (p. 65). When direct speech is turned into indirect speech, some changes are usually necessary, such as tenses, pronoun, and adverb. In this case, Azar (1992) says that indirect speech refers to reproducing the idea of another person's words. Not all the exact words are used; verb form and pronouns may change.

Furthermore, it is necessary to learn about indirect speech because it is one of many grammatical categories which is important to be learnt by students as it is one of three ways for students to report or share their statements or thoughts to other people especially when they communicate each other. Murcia \& Freeman (1999) say, "Grammar and rhetoric books generally recognize three ways for a speaker and writer to attribute statements or thoughts to other people: direct quotation, indirect or reported speech, and paraphrase"(p.687.) Besides, it is essential for students to learn indirect speech because it is one of the linguistic features which should be mastered by students when they try to write a report text or sentences, and also it cannot be denied that it has important role because it is often used by people to communicate in their daily conversation. Furthermore, in writing product, transforming direct into indirect speech is necessary to be grammatically correct. Consequently, in order to be able to produce a correct sentence, a writer must have ability in grammar. L.G. Alexander (1967) says that writing exercise is primarily on grammar. By using the right grammar 
someone can express his feelings, ideas, or thoughts clearly. If there are some mistakes of using grammar, the sentences will be difficult to comprehend.

English is not our mother tongue, so that the errors in using English are commonly happen. The errors also happen when students learn indirect speech.The current phenomena show that many students at SMA 2 Peusangan still have difficulties in understanding indirect speech. The teacher notices that they often do mistakes when they transform the direct into indirect form. Some students are still confused with certain grammatical changes that have to be made by them. Sometimes they feel so hard to decide what kind of tenses and pronoun that should be used when they turn the word. For example:

- Direct speech : Ann said, "I am hungry."

- Indirect speech : Ann said that she was hungry.

In relation to discussion, direct speech refers to reproducing a speaker's exact words and using quotation marks. In indirect speech, not all of the speaker's exact words are used, verbs and pronoun may change, and quotation marks are not used. From the example above, we can see that simple present tense in direct speech is changed into simple past tense, and pronoun is also changed in indirect speech. Most of the students cannot differ and remember the changes. In this case, Parrott (2010) mentions, "Learners are sometimes confused by the tense and pronoun changes that can occur in reported speech" (p.257).

In teaching and learning process, it is necessary to analyze the errors in order to give the teacher information on students' competence in target language. How far they understand it and where the areas of difficulties are. Furthermore, an error analysis on students' work will be useful and give some contributions to the process of teaching and learning. Analyzing error 
is significant since this will lead to a greater understanding of the difficulties that the students face and assist in the development of pedagogic strategies. Error analysis in transforming direct to indirect speech is necessary because so many students still have difficulties in doing this. The students of SMA Negeri 2 Peusangan face that problem. The previous study had been done by Keumalasari at second year students of SMA PeukanBiluy, Aceh Besar. The result showed that students still make errors in transforming direct to indirect speech. The most error was done in changing tenses (Keumalasari, 1999). Based on the description above, the writer would like to conduct the research on the error analysis of the transformation from direct speech to indirect speech that made by the second year students of SMA Negeri 2 Peusangan.

\section{LITERATURE REVIEW}

\section{An Overview of Grammar}

Richards (1985) defines grammar as a description of the structure of a language and how to describe linguistic units such as words and phrases are combined to make a correct sentence. It usually takes into account the meanings and functions these sentences have in the overall system of the language. It may or may not include the description of the sounds of a language.

\section{The Definition of Direct Speech}

Direct speech is someone's statements said orally by the speaker. In the classroom context, for instance: teachers ask students to quote what their mothers said. For example: Mother said, "Rina, you have to wake up earlier." This activity assists students to understand what the direct speech is.

To see the definition of direct speech, the writer also quotes a 
description given in Fundamentals of English Grammar by Azar (1992), “Sometimes we want to quote a speaker's words. Exact quotations are used in many kinds of writing, such as newspaper articles, stories and novels, and academic papers. When we quote a speaker's words, we used quotation mark" (p.364). Moreover, Richard (1985) mentions that direct speech is the style used in writing to report what a speaker actually said, without introducing any grammatical changes. In English the speaker's words may be written between quotation marks.

The following examples should clarify the description above:

\section{Speaker Speaker's exact words}

Jane : Cats are fun to watch.

Mike $\quad$ : Yes, I agree. They are graceful and playful. Do you own a cat?

\section{Quoting the speaker's words (Direct Speech)}

Jane said, "Cats are fun to watch."

Mike said, "Yes, I agree. They are graceful and playful. Do you own a cat?"

From the examples above, direct speech is a speech by which the speaker directly quotes exactly what the first speaker has spoken. Thomson and Martinet (1986) in their book A Practical English Grammar as cited in Suhandi (2008) say that we repeat the original speaker's exact words in quoted speech.

\section{The Definition of Indirect Speech}

Azar (1992) says that another person's words and thoughts are reproduced in indirect speech, but not all the exact words are used; verb form and pronouns may change. Indirect speech is used to communicate 
what someone else said, but without using the exact words. Furthermore, Oshima (2006) says that in indirect speech, the speaker's or writer's words were reported indirectly, without quotation marks. Indirect speech is introduced by the same reporting verbs used for direct quotations, and the word that is often added for clarity, but it is optional.

Pollock (1982) as quoted by Suhandi (2008) also says that say and tell are usually used to introduce reported statement. However, for variety we may use other introductory verbs that fit the sentences, such as announce, declare, mention, warn, promise, and explain. In reported speech, these words are not followed immediately by an object pronoun except the word promise.

For examples:

- The teacher said, "The examination will be held on Monday."

The teacher announced (that) the examination would be held on Monday.

- The president said, "Our country is saved."

The president declared (that) their country was saved.

- She said, "I can handle this project."

She remarked (that) she could handle that project.

- Tom said, "You will not pass the exam."

Tom denied (that) I would not pass the exam.

- Ann said, "This shop does not give a good service for customers." Ann complained (that) that shop did not give a good service for customers.

- He said, "You should not go back anymore."

He mentioned (that) I should not go back anymore.

- Mary said, "I will come to your party."

Marry answered (that) she would come to my party. 
- The teacher said, "We should not look directly at the sun during a solar eclipse."

The teacher explained (that) they should not look directly at the sun during a solar eclipse.

- Alice said, "I will take you home after the class is over."

Alice promised me (that) she would take me home after the class was over.

From the examples above, there is only the word promise which is followed by object pronoun. According to Azar (1988), say is followed immediately by a noun clause, but tell is not followed immediately by a noun clause. Tell is followed immediately by an object pronoun (e.g.: me, us, Jhon, someone) and then by a noun clause.

For examples:

- Ann said that she was hungry.

- Ann told me that she was hungry.

\section{Changes in Indirect Speech}

There are several aspects that shoud be changed in transforming direct to indirect speech, they are:

- Changing of tenses (Simple present to simple past, Present continuous to past continuous, Present perfect to past perfect, Present perfect continuous to past perfect continuous, Simple past to past perfect, and Past continuous to past perfect continuous)

- Changing of pronoun (pronoun and possessive adjectives usually change from first or second person to third person except when the speaker is reporting his own words).

- Changing of adverb of time: 
Direct

today

tonight

this

these

now

yesterday

last week

next month

next year

\section{Indirect}

that day

that night

that

those

at that time

the previous day

the previous week

the following month

the following year

\section{RESEARCH METHODOLOGY}

The methodology used was descriptive quantitative. It was meant that this study used numbers and statistical technique to analyze the data collected. The research was intended to describe the reality found without giving any manipulation. It dealt with a single variable, analyzing the errors, which was focused on the transformation from direct to indirect speech made by the students. The students' errors on the test were used as the indicator of analysis.

The population was the second grade students of SMA Negeri 2 Peusangan. The total numbers of the population were 295 students which were divided in 7 classes; four Science Program classes (IPA) and three Social Program classes (IPS).

Since the students were taught by the teacher using the same textbook and materials with the same curriculum, all of the second classes had the same ability in understanding direct and indirect speech, so that the writer used random sampling as technique of taking sample. In the process 
of taking sample, the writer used lottery procedure. There were three steps in this procedure; first, the writer collected all second classes' name in a box and shook it likes a lottery. After that, the writer got one class as the sample.

To get the data, the writer administered a grammar test which was divided in two sections; multiple choices item and essay test. The test was made by the writer herself by consulting with the English teacher of SMA Negeri 2 Peusangan.

To score the test, the writer used the following formula:

$$
\text { Score }=\frac{B}{N} \times 100
$$

Where:

B: Right answer

$\mathrm{N}$ : Total of the test item

\section{FINDINGS AND DISCUSSIONS}

Two sections of test containing items about the changing direct into indirect speech were given to the students in order to know in what transformation they produced the most errors. Here is the detail of the data.

Table 1

The Scores of Students

\begin{tabular}{|l|l|c|}
\hline No & Students' Number & Scores \\
\hline 1 & 9634 & 55 \\
\hline 2 & 9716 & 25 \\
\hline 3 & 9909 & 79 \\
\hline 4 & 9639 & 12 \\
\hline 5 & 9640 & 48 \\
\hline 6 & 9642 & 43 \\
\hline 7 & 9678 & 25 \\
\hline
\end{tabular}




\begin{tabular}{|c|c|c|}
\hline 8 & 9644 & 18 \\
\hline 9 & 9645 & 49 \\
\hline 10 & 9646 & 54 \\
\hline 11 & 9647 & 49 \\
\hline 12 & 9648 & 42 \\
\hline 13 & 9649 & 28 \\
\hline 14 & 9651 & 40 \\
\hline 15 & 9738 & 29 \\
\hline 16 & 9653 & 53 \\
\hline 17 & 9742 & 34 \\
\hline 18 & 9654 & 37 \\
\hline 19 & 9655 & 40 \\
\hline 20 & 9699 & 36 \\
\hline 21 & 9656 & 78 \\
\hline 22 & 9751 & 36 \\
\hline 23 & 9657 & 49 \\
\hline 24 & 9707 & 12 \\
\hline 25 & 9658 & 31 \\
\hline 26 & 9659 & 28 \\
\hline 27 & 9660 & 37 \\
\hline 28 & 9661 & 20 \\
\hline 29 & 9662 & 60 \\
\hline 30 & 9664 & 52 \\
\hline 31 & 9665 & 49 \\
\hline 32 & 9666 & 65 \\
\hline 33 & 9667 & 24 \\
\hline
\end{tabular}




\begin{tabular}{|l|l|l|}
34 & 9712 & 15 \\
\hline
\end{tabular}

From the data above, the highest score is 79 and the lowest score is 12. Sudjana (2002) defines the range of the score is the highest score minus the lowest score. It is showed as follows:

$\mathrm{R}=$ the highest score - the lowest score

$$
=79-12=67
$$

The amount of class interval $(\mathrm{K})$ is counted by using the suggested formula (here, $\mathrm{n}$ is the number of students), that is:

$$
\begin{aligned}
\mathrm{K} & =1+3,3 \log \mathrm{n} \\
& =1+3,3 \log 34 \\
& =1+3,3(1,53) \\
& =1+5 \\
& =6
\end{aligned}
$$

The length of class interval $(\mathrm{P})$ can be found by dividing the range with the amount of class interval, as follows:

$$
\begin{aligned}
\mathrm{P} & =\frac{R}{K} \\
& =\frac{67}{6} \\
& =11,16
\end{aligned}
$$

The distribution of frequency is shown on table 2 . 
Table 2

'The Distribution of Frequency

\begin{tabular}{|c|c|c|c|c|c|c|}
\hline No & $\begin{array}{c}\text { Class } \\
\text { Interval }\end{array}$ & $\mathrm{f}_{\mathrm{i}}$ & $\mathrm{x}_{\mathrm{i}}$ & $x_{i}^{2}$ & $\mathrm{f}_{\mathrm{i}} \mathrm{x}_{\mathrm{i}}$ & $\left(\mathrm{f}_{\mathrm{i}} \mathrm{x}_{\mathrm{i}}\right)^{2}$ \\
\hline 1 & $10-21$ & 5 & 16 & 256 & 80 & 6.400 \\
\hline 2 & $22-33$ & 7 & 28 & 784 & 196 & 38.416 \\
\hline 3 & $34-45$ & 9 & 40 & 1600 & 360 & 129.600 \\
\hline 4 & $46-57$ & 9 & 52 & 2704 & 468 & 219.024 \\
\hline 5 & $58-69$ & 2 & 64 & 4096 & 128 & 16.384 \\
\hline 6 & $70-81$ & 2 & 76 & 5776 & 152 & 23.104 \\
\hline \multicolumn{2}{|c|}{ Total } & 34 & & & 1.384 & 432.928 \\
\hline
\end{tabular}

Based on the data above, we get mean $(\bar{X})$ and variants $\left(S^{2}\right)$ as follows:

$$
\begin{aligned}
\bar{X} & =\frac{\Sigma f_{i} x_{i}}{\Sigma f_{i}}=\frac{1.384}{34}=40,7 \\
S^{2} & =\frac{n \Sigma f_{i} x_{i}^{2}-\left(\Sigma f_{i} x_{i}\right)^{2}}{n(n-1)} \\
& =\frac{34(432.928)-(1384)^{2}}{34(33)} \\
& =\frac{12.804 .096}{1122} \\
& =11.411,8 \\
S & =106,8
\end{aligned}
$$


After finding the mean $(\bar{X})$ and variants $\left(S^{2}\right)$, we can get the reliability of the test by using the formula suggested by Sudjana (2002) as follows:

$$
\begin{aligned}
R & =\left(\frac{n}{n-1}\right)\left(1-\frac{\bar{X}(n-\bar{X})}{n S^{2}}\right) \\
& =\left(\frac{34}{34-1}\right)\left(1-\frac{40,7(34-40,7)}{34(11.411,8)}\right) \\
& =\left(\frac{34}{33}\right)\left(1-\frac{40,7(-6,7)}{388.001,2}\right) \\
& =1,03\left(1-\frac{272,69}{388.001,2}\right) \\
& =1,03(0,9) \\
& =0,92
\end{aligned}
$$

\begin{tabular}{|c|c|c|}
\hline No & Area Tested & Number of Items \\
\hline \multirow[t]{6}{*}{$\mathrm{I}$} & $\begin{array}{l}\text { Transforming the direct speech into } \\
\text { indirect speech by applying the rule for } \\
\text { sequence of tenses: } \\
\text { Simple present-simple past }\end{array}$ & $\begin{array}{l}1,3,5,8,10,11,18,19,21,2 \\
9,30\end{array}$ \\
\hline & Present continuous-past continuous & 7,22 \\
\hline & Present perfect-past perfect & $6,9,13,25,26$ \\
\hline & $\begin{array}{l}\text { Present perfect continuous-past perfect } \\
\text { continuous }\end{array}$ & 20 \\
\hline & Simple past-past perfect & $2,14,15,16,17,23,27$ \\
\hline & $\begin{array}{l}\text { Past continuous-past perfect } \\
\text { continuous }\end{array}$ & $4,12,4,8$ \\
\hline
\end{tabular}

Results of the calculation are shown on the following tables: (Table 3)

Area Tested of Change Tenses, Pronoun, and Adverb of Time 


\begin{tabular}{|c|c|c|}
\hline \multirow[t]{5}{*}{ II } & $\begin{array}{l}\text { Transforming the direct speech into } \\
\text { indirect speech with suitable pronouns: } \\
\text { The } 1 \text { st and } 2 \text { nd person turns into 3rd } \\
\text { person; } \\
\text { 1. My-her/his }\end{array}$ & $1,6,7,16,17,19,26,28$ \\
\hline & 2.You-he/she/they/me & $4,9,20,24,27,30$ \\
\hline & 3.We-they & $13,21,29$ \\
\hline & 4.I-he/she & $\begin{array}{l}1,2,5,6,7,8,9,10,11,12,14 \\
, 15,18,20,22,23,25,27,2 \\
8,30\end{array}$ \\
\hline & 5.Me-him/her & $3,19,26,28$ \\
\hline \multirow[t]{9}{*}{ III } & $\begin{array}{l}\text { Transforming the direct speech into } \\
\text { indirect speech with suitable adverb of } \\
\text { time: }\end{array}$ & \\
\hline & now-then, at that time & 18,22 \\
\hline & today-that day & 21 \\
\hline & last night-the previous night & 4 \\
\hline & yesterday-the day before & 2 \\
\hline & next year-the following year & 10,29 \\
\hline & tomorrow-the following day & 11 \\
\hline & last year-the previous year & 12 \\
\hline & last week-the previous week & 15,23 \\
\hline
\end{tabular}


Table 4

Frequency of Error Made in the Change of Tenses

\begin{tabular}{|c|c|c|c|c|}
\hline No & Change of Tenses & $\begin{array}{c}\text { Item } \\
\text { Number }\end{array}$ & $\begin{array}{c}\text { Frequency } \\
\text { of } \\
\text { Error Made }\end{array}$ & Percentage \\
\hline 1 & Simple Present to Simple Past & 1 & 8 & $23,52 \%$ \\
\hline 2 & Simple Present to Simple Past & 3 & 15 & $44,11 \%$ \\
\hline 3 & Simple Present to Simple Past & 5 & 7 & $20,58 \%$ \\
\hline 4 & Simple Present to Simple Past & 8 & 13 & $38,23 \%$ \\
\hline 5 & Simple Present to Simple Past & 10 & 6 & $17,64 \%$ \\
\hline 6 & Simple Present to Simple Past & 11 & 5 & $14,7 \%$ \\
\hline 7 & Simple Present to Simple Past & 18 & 12 & $35,29 \%$ \\
\hline 8 & Simple Present to Simple Past & 19 & 10 & $29,41 \%$ \\
\hline 9 & Simple Present to Simple Past & 21 & 21 & $61,76 \%$ \\
\hline 10 & Simple Present to Simple Past & 29 & 14 & $41,17 \%$ \\
\hline 11 & Simple Present to Simple Past & 30 & 18 & $52,94 \%$ \\
\hline 12 & $\begin{array}{c}\text { Present Continuous to Past } \\
\text { Continuous }\end{array}$ & 7 & 8 & $23,52 \%$ \\
\hline 13 & $\begin{array}{c}\text { Present Continuous to Past } \\
\text { Continuous }\end{array}$ & 22 & 20 & $58,82 \%$ \\
\hline 14 & Present Perfect to Past Perfect & 6 & 7 & $20,58 \%$ \\
\hline
\end{tabular}




\begin{tabular}{|c|c|c|c|c|}
\hline 15 & Present Perfect to Past Perfect & 9 & 13 & $38,23 \%$ \\
\hline 16 & Present Perfect to Past Perfect & 13 & 6 & $17,64 \%$ \\
\hline 17 & Present Perfect to Past Perfect & 25 & 9 & $26,47 \%$ \\
\hline 18 & Present Perfect to Past Perfect & 26 & 20 & $58,82 \%$ \\
\hline 19 & $\begin{array}{l}\text { Present Perfect Continuous to } \\
\text { Past Perfect Continuous }\end{array}$ & 20 & 7 & $20,58 \%$ \\
\hline 20 & Simple Past to Past Perfect & 2 & 14 & $41,17 \%$ \\
\hline 21 & Simple Past to Past Perfect & 14 & 20 & $58,82 \%$ \\
\hline 22 & Simple Past to Past Perfect & 15 & 15 & $44,11 \%$ \\
\hline 23 & Simple Past to Past Perfect & 16 & 17 & $50 \%$ \\
\hline 24 & Simple Past to Past Perfect & 17 & 19 & $55,88 \%$ \\
\hline 25 & Simple Past to Past Perfect & 23 & 17 & $50 \%$ \\
\hline 26 & Simple Past to Past Perfect & 27 & 21 & $61,76 \%$ \\
\hline 27 & $\begin{array}{c}\text { Past Continuous to Past } \\
\text { Perfect Continuous }\end{array}$ & 4 & 20 & $58,82 \%$ \\
\hline 28 & $\begin{array}{c}\text { Past Continuous to Past } \\
\text { Perfect Continuous }\end{array}$ & 12 & 12 & $35,29 \%$ \\
\hline 29 & $\begin{array}{c}\text { Past Continuous to Past } \\
\text { Perfect Continuous }\end{array}$ & 24 & 20 & $58,82 \%$ \\
\hline 30 & $\begin{array}{l}\text { Past Continuous to Past } \\
\text { Perfect Continuous }\end{array}$ & 28 & 19 & $55,88 \%$ \\
\hline & Total (Px) & & 413 & $40,5 \%$ \\
\hline
\end{tabular}


To find out the frequency error made by the students in change each tenses, the writer used formula: $\mathrm{P}=\frac{F}{N} \times 100 \%$

To find out total frequency error made by the students in change of tenses, the writer used formula:

$\mathrm{P}=\frac{F}{N x n} \times 100 \%=\frac{413}{34 \times 30} \times 100 \%=40,05 \%$

These are the items related to the students' difficulty in the change of tense in transformation from direct speech into indirect speech. First, the writer discussed about the change of simple present to simple past. There are 8 students or $23,5 \%$ who made error in item number 1 , there are 15 students or $44,11 \%$ who made error in item number 3 , there are 7 students or 20,58 $\%$ who made error in item number 5 , there are 13 students or $38,23 \%$ who made error in item number 8 , there are 6 students or 17,64\% who made error in item number 10 , there are 5 students or $14,7 \%$ who made error in item number 11, there are 12 students or 35,29 \% who made error in item number 18 , there are 10 students or $29,41 \%$ who made error in item number 19 , there are 21 students or $61,76 \%$ who made error in item number 21 , there are 14 students or $41,17 \%$ who made error in item number 29, there are 18 students or 52,94\% who made error in item number 30 .

Second, the writer discussed about the change of present continuous to past continuous. There are 8 students or $23,52 \%$ who made error in item number 7 , and there are 20 students or $58,82 \%$ who made error in item number 22.

Third, the writer discussed about the change of present perfect to past perfect. There are 7 students or 20,58 \% who made error in item number 6 , there are 13 students or $38,23 \%$ who made error in item number 9, there are 6 students or $17,64 \%$ who made error in item number 13 , there are 9 
students or $26,47 \%$ who made error in item number 25 , and there are 20 students or $58,82 \%$ who made error in item number 26 .

Fourth, the writer discussed about the change of present perfect continuous to past perfect continuous. There are 7 students or $20,58 \%$ who made error in item number 20.

Fifth, the writer discussed about the change of simple past to past perfect. There are 14 students or $41,17 \%$ who made error in item number 2 , there are 20 students or 58,82\% who made error in item number 14, there are 15 students or $44,11 \%$ who made error in item number 15 , there are 17 students or $50 \%$ who made error in item number 16 , there are 19 students or $55,88 \%$ who made error in item number 17 , there are 17 students or $50 \%$ who made error in item number 23 , and there are 21 students or $61,76 \%$ who made error in item number 27.

Sixth, the writer discussed about the change of past perfect to past perfect continuous. There are 20 students or $58,82 \%$ who made error in item number 4 , there are 12 students or 35,29 \% who made error in item number 12 , there are 20 students or $58,82 \%$ who made error in item number 24 , and there are 19 students or 55,88\% who made error in item number 28 .

The total averages of frequency error made by students are $33 \%$ students who got difficulty in the change of tenses.

In the next table, writer discussed the frequency of error made in the change of pronoun. The data will be shown as follows; 
Table 5

Frequency of Error Made in the Change of Pronoun

\begin{tabular}{|c|c|c|c|c|}
\hline $\begin{array}{l}\mathbf{N} \\
\mathbf{O}\end{array}$ & Changes of Pronoun & $\begin{array}{c}\text { Item } \\
\text { Number }\end{array}$ & $\begin{array}{c}\text { Frequency } \\
\text { of Error } \\
\text { made }\end{array}$ & Percentage \\
\hline 1 & My become her & 6 & 8 & $23,52 \%$ \\
\hline 2 & My become her & 7 & 12 & $35,29 \%$ \\
\hline 3 & My become her & 16 & 18 & $52,94 \%$ \\
\hline 4 & My become her & 28 & 27 & $42 \%$ \\
\hline 5 & My become his & 17 & 29 & $85,29 \%$ \\
\hline 6 & My become his & 19 & 32 & $94,11 \%$ \\
\hline 7 & My become his & 3 & 33 & $97,05 \%$ \\
\hline 8 & You become be & 4 & 13 & $38,23 \%$ \\
\hline 9 & You become be & 20 & 15 & $44,11 \%$ \\
\hline 10 & You become her & 9 & 17 & $50 \%$ \\
\hline 11 & You become her & 27 & 31 & $91,17 \%$ \\
\hline 12 & You become his & 30 & 29 & $85,29 \%$ \\
\hline 13 & You become they & 24 & 33 & $97,05 \%$ \\
\hline 14 & You become they & 21 & 17 & $50 \%$ \\
\hline 15 & You become they & 29 & 28 & $82,35 \%$ \\
\hline 16 & $I$ become he & 1 & 19 & $55,88 \%$ \\
\hline 17 & I become he & 5 & 12 & $35,29 \%$ \\
\hline 18 & I become he & 8 & 14 & $41,17 \%$ \\
\hline 19 & I become he & 9 & 19 & $55,88 \%$ \\
\hline 20 & $I$ become he & 10 & 23 & $67,64 \%$ \\
\hline 21 & $I$ become be & 12 & 29 & $85,29 \%$ \\
\hline
\end{tabular}




\begin{tabular}{|c|c|c|c|c|}
\hline 22 & I become he & 14 & 17 & $50 \%$ \\
\hline 23 & I become $h e$ & 20 & 16 & $47,05 \%$ \\
\hline 24 & I become he & 22 & 15 & $44,11 \%$ \\
\hline 25 & I become he & 27 & 12 & $35,29 \%$ \\
\hline 26 & I become she & 2 & 12 & $35,29 \%$ \\
\hline 27 & $I$ become she & 6 & 9 & $26,47 \%$ \\
\hline 28 & I become she & 7 & 13 & $38,23 \%$ \\
\hline 29 & I become she & 11 & 25 & $73,52 \%$ \\
\hline 30 & I become she & 15 & 27 & $79,41 \%$ \\
\hline 31 & $I$ become she & 18 & 27 & $79,41 \%$ \\
\hline 32 & I become she & 23 & 30 & $88,23 \%$ \\
\hline 33 & $I$ become she & 25 & 29 & $85,29 \%$ \\
\hline 34 & I become she & 28 & 33 & $97,05 \%$ \\
\hline 35 & $I$ become she & 30 & 21 & $61,76 \%$ \\
\hline 36 & Me become $\mathrm{bim}$ & 3 & 25 & $73,52 \%$ \\
\hline 37 & Me become him & 19 & 32 & $94,11 \%$ \\
\hline 38 & Me become him & 26 & 32 & $94,11 \%$ \\
\hline \multirow[t]{2}{*}{39} & Me become her & 28 & 30 & $88,23 \%$ \\
\hline & Total (Px) & & 863 & $65 \%$ \\
\hline
\end{tabular}

To find out the frequency error made by the students in changing pronoun, the writer used formula:

$$
\mathrm{P}=\frac{F}{N} x 100 \%
$$

To find out total frequency error made by the students in change of pronoun, the writer used formula:

$\mathrm{P}=\frac{F}{N x n} \times 100 \%=\frac{863}{34 \times 39} \times 100 \%=65 \%$ 
In the next table, writer discussed the frequency of error made in the change of adverb of time. The data will be shown as follows;

Table 6

Frequency of Error Made in the Change of Adverb of Time

\begin{tabular}{|l|l|c|c|l|}
\hline $\begin{array}{c}\mathbf{N} \\
\mathbf{o}\end{array}$ & Changes of Adverb of Time & $\begin{array}{c}\text { Item } \\
\text { Number }\end{array}$ & $\begin{array}{c}\text { Frequency } \\
\text { of Error } \\
\text { made }\end{array}$ & Percentage \\
\hline 1 & Now become at that time, then & 18 & 8 & $23,52 \%$ \\
\hline 2 & Now become at that time, then & 22 & 15 & $44,11 \%$ \\
\hline 3 & Today become that day & 21 & 8 & $23,52 \%$ \\
\hline 4 & $\begin{array}{l}\text { Last night become the previous } \\
\text { night, the night before }\end{array}$ & 4 & 14 & $41,17 \%$ \\
\hline 5 & Yesterday become the day before & 2 & 9 & $26,47 \%$ \\
\hline 6 & $\begin{array}{l}\text { Next year } \text { become the following } \\
\text { year }\end{array}$ & 10 & 6 & $17,64 \%$ \\
\hline 7 & $\begin{array}{l}\text { Next year } \text { become the following } \\
\text { year }\end{array}$ & 29 & 16 & $47 \%$ \\
\hline 8 & $\begin{array}{l}\text { Tomorrow } \text { become the following } \\
\text { day }\end{array}$ & 11 & 2 & $5,88 \%$ \\
\hline 9 & $\begin{array}{l}\text { Last year } \text { become the previous } \\
\text { year }\end{array}$ & 12 & 7 & $20,58 \%$ \\
\hline 10 & $\begin{array}{l}\text { Last week become the previous } \\
\text { week }\end{array}$ & 15 & 6 & $17,64 \%$ \\
\hline 11 & Last week become the previous week & 23 & 15 & $44,11 \%$ \\
\hline Total (Px) & $\mathbf{2 8 6} \%$ \\
\hline
\end{tabular}


To find out the frequency error made by the students in changing adverb of time, the writer used formula:

$$
\mathrm{P}=\frac{F}{N} x 100 \%
$$

To find out total frequency error made by the students in change of adverb of time, the writer used formula:

$$
\mathrm{P}=\frac{F}{N x n} \times 100 \%=\frac{106}{34 x 11} \times 100 \%=28 \%
$$

After classifying the items into area tested and analyzing the frequency of error in each item, the writer described the difficulty in the change of tense, pronoun, and adverb of time in transformation direct speech into reported speech in form of statement in the percentage as follows:

\begin{tabular}{|l|l|c|}
\hline No. & \multicolumn{1}{|c|}{ Difficulties } & Percentage \\
\hline 1. & $\begin{array}{l}\text { The change of tense in transformation direct speech } \\
\text { into indirect speech }\end{array}$ & $40,5 \%$ \\
\hline 2. & $\begin{array}{l}\text { The change of pronoun in transformation direct } \\
\text { speech into indirect speech }\end{array}$ & $65 \%$ \\
\hline 3. & $\begin{array}{l}\text { The change of adverb of time in transformation } \\
\text { direct speech into indirect speech }\end{array}$ & $28 \%$ \\
\hline
\end{tabular}

The table above shows that many students made error in the change of tense, pronoun and adverb of time. There are 40,5\% students who made error in the change of tense in transformation direct speech into reported speech, $65 \%$ students who made error in the change of pronoun in the transformation direct speech into indirect speech, and $28 \%$ students made error in the change of adverb of time in the transformation direct speech into indirect speech. However, the higher difficulty in learning indirect speech is 
in the change of pronoun.

Furthermore, the writer can interpret that most of the second year students of SMA Negeri 2 Peusangan still hard to change the tenses and pronouns in the right form in converting direct speech into reported speech of statements. The writer also noticed they confused to change the time of the original statement uttered to the time of indirect statement and the speaker that was of $1^{\text {st }}$ and $2^{\text {nd }}$ person turned into $3^{\text {rd }}$ person. Then, having opinion that grammar is difficult, less enthusiasm and motivation caused the students get difficulties in reported speech of statement. Besides, they did not understand yet the explanation given by the teacher.

\section{Conclusion and Suggestions}

Based on the data analysis discussed in the previous chapter, the writer inferred most of the students made errors in the change of pronoun when they transformed the direct speech into indirect speech. The data showed that the difficulty in the change of pronoun has the highest percentage of error. It was about $65 \%$ error made by students. It means the rate of the students' mastery in this subject is still low enough especially in grammatical changes therefore it is collocated the change of pronoun in the first while the change of tense is in the second rank, and the change of adverb of time in the third rank.

This study also suggests that students should understand very well how to change the direct speech into indirect speech and memorize the rule for the sequence of tense, pronoun, and adverb of time in its transformation. Meanwhile, the teacher should create the class comfortable for studying and do an improvisation to attract students' enthusiasm and motivation in teaching-learning process. 


\section{REFERENCES}

Alexander, L. G. (1967). Practice and progress. London: Longman Group Limited.

Arikunto, S.( 2002). Prosedur penelitian; Suatu pendekatan praktek. Jakarta: Rineka Cipta.

Azar, B. S. (1992). Fundamentals of English grammar. (2nd Ed.). New York: Pearson Education.

Borg, W. R. (1989). Educational research. New York: Pitman Publishing.

Brians, P. (2005). Common errors in English: Kesalaban-kesalahan umum dalam Bahasa Inggris. Yogyakarta: Diglossia.

Brown, D. (2004). Language Assesment. Principles and classroom practices. New York: Pearson Education.

Corder, S. P. (1981). Error analysis and interlanguage. London: Oxford University Press.

Heaton, J. B. (1988). Writing English language tests. London: Longman.

Hornby, A. S. (1974). Oxford Advanced Learner's Dictionary of Current English. Oxford: Oxford University Press.

Keumalasari, C. (1999). Errors in changing direct into indirect sentences.(Bachelor thesis). Syiah Kuala University, Banda Aceh.

Littlewood. W. (1984). Foreign and second language learning. Newyork: Cambridge University Press.

Manajemen Penelitian. (2005). Jakarta: Rineka Cipta.

Marjannah, L. (n.d.). Buku Ajar Acuan Pengayaan Babasa Inggris. Solo: CV. Sindunata.

Murcia, M. C and Freeman, D.L. (1999). The grammar book an ESL/EFL teacher's course. (2nd Ed.). Boston: Heinle and Heinle Publisher. 
Nunan, David. (1999). Second language teaching and learning grammar. Boston: Heinle and Heinle Publisher.

Oshima, A. (2006). Writing academic English. NY: Pearson Education.

Parrott, M. (2010). Grammar for English language teachers. Cambridge: Cambridge University Press.

Richards, J. (1985). Longman dictionary of applied linguistics. London: Longman Group Limited.

Sudijono, A. (2006). Pengantar statistik pendidikan. Jakarta: PT. Raja Grafindo.

Sudjana. (2002). Metoda statistika. Bandung: PT. Tarsito.

Suhandi. (2008). Students performance in understanding indirect speech. (Bachelor thesis).Syiah Kuala University, Banda Aceh.

Ur. P. (1996). A course in language teaching.New York: Cambridge University Press. 